\title{
A cyclin-dependent kinase inhibitor (p2|WAFI/CIPI $)$ affects thymidine incorporation in human liver cancer cells
}

\section{Y Gong*,1,2, S Deng', M Zhang',2, G Wang ${ }^{3}$, GY Minuk' and F Burczynski ${ }^{3}$}

'Department of Internal Medicine, Faculty of Medicine, University of Manitoba, Winnipeg, Manitoba, Canada; ${ }^{2}$ Department of Biochemistry and Medical Genetics, Faculty of Medicine, University of Manitoba, Winnipeg, Manitoba, Canada; ${ }^{3}$ Faculty of Pharmacy, University of Manitoba, Winnipeg, Manitoba, Canada

$\mathrm{p} 2 \mathrm{I}^{\mathrm{WAFI} / \mathrm{CIPI}}$ is a universal cyclin-dependent kinase inhibitor. To investigate the role of p2 $\mathrm{I}^{\mathrm{WAFI} / \mathrm{CIPI}}$ in proliferation of human liver cancer cells, we examined the expression of p53, p2 I WAFI/CIPI, cdk2 and cdk4 expression in two human liver cancer cell lines (HepG2 and PLC/PRF/5 cells). The effects of p2 $I^{\text {WAFI/CIPI }}$ on $\left[{ }^{3} \mathrm{H}\right]$ thymidine incorporation and cdks were also examined in these cells. HepG2 cells expressed all these proteins with lower level of cdk4. PLC/PRF/5 cells expressed the other proteins except $p 2 I^{\text {WAFI/CIPI }}$. Transfection of $\mathrm{p} 2 \mathrm{I}^{\mathrm{WAFI} / \mathrm{CIPI}}$ gene inhibited $\left[{ }^{3} \mathrm{H}\right]$ thymidine incorporation of both cells with different extent. Although the transfection of $\mathrm{p} 2 \mathrm{I}^{\mathrm{WAFI} / \mathrm{CIPI}}$ did not affect cdk 2 and cdk4 expression, it did reduce cdk2 kinase activity

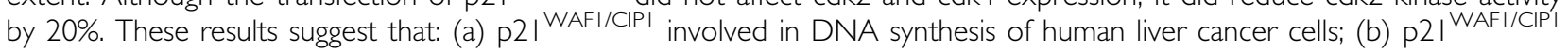
could be a target gene for the treatment of human hepatocellular carcinoma.

British Journal of Cancer (2002) 86, 625-629. DOI: 10.1038/sj/bjc/6600099 www.bjcancer.com

(c) 2002 Cancer Research UK

Keywords: P2I WAFI/CIPI $;{ }^{3}$ H]thymidine incorporation; liver cancer

The cyclins and the cyclin-dependent kinases (cdks) are important proteins regulating the checkpoints of cell cycle progression (Hunter and Pines, 1994). In normal cells, checkpoints in the cell cycle play an important role of guiding normal cell cycle while in cancer cells, disruption of the checkpoints is responsible to abnormal growth of cancer cells. Positive and negative regulatory mechanisms control the regulation of the checkpoints in cell cycle. A cyclin-dependent kinase inhibitor (cdki) mediates one of the negative regulations of checkpoints (Sherr and Roberts, 1995). Recently, the p21 WAF1/CIP1 gene was cloned and mapped to the chromosome $6 \mathrm{p} 21.2$ region (el-Deiry et al, 1993; Noda et al, 1994). p21 $21^{\mathrm{WAF} 1 / \mathrm{CIP} 1}$ is considered a universal cyclin-dependent kinase inhibitor. It inhibits several cyclin-cdks complex as well as DNA synthesis by inactivating proliferation cell nuclear antigen, a subunit of DNA polymerase $\delta$ (Xiong et al, 1993). In addition, p21 $1^{\mathrm{WAF} 1 / \mathrm{CIP} 1}$ involves in induction of cell differentiation (Skapek et al, 1995) and inhibition of tumour cell proliferation (el-Deiry et al, 1994).

Mutation of $\mathrm{p} 21^{\mathrm{WAF} 1 / \mathrm{CIP} 1}$ is rare in different types of human malignancy, therefore, it is suggested that $\mathrm{p} 21^{\mathrm{WAF} 1 \mathrm{CIP} 1}$ exerts its role in tumorigenesis mainly on expression level. It seems to be true in human hepatocellular carcinoma (HCC). Several groups studying expression of $\mathrm{p} 21^{\mathrm{WAF} 1 / \mathrm{CIP1}}$ in human hepatocellular carcinoma have documented that there were reduced p21 2 WAF1/CIP1 mRNA and protein levels in human HCC (Hui et al, 1997; Naka et al, 1998; Qin et al, 1998; Shi et al, 2000). These studies suggested that disruption of $\mathrm{p} 21^{\mathrm{WAF} 1 / \mathrm{CIP} 1}$ and cell cyclin-cdks complexes may contribute to malignant progression of HCC. However, the direct role of $\mathrm{p} 21^{\mathrm{WAF} 1 / \mathrm{CIP}^{1}}$ in human HCC cells has not been explored.

*Correspondence: Dr Y Gong, John Buhler Research Centre, 803G, 715 McDermot Avenue, Winnipeg, Manitoba, Canada, R3E 3P4;

E-mail: ygong@ms.umanitoba.ca

Received 2 February 200I; revised 6 November 200I; accepted 23 November 2001
In this study, we employ an expression vector of $\mathrm{p} 21^{\mathrm{WAF} 1 / \mathrm{CIP} 1}$ to examine the direct effect of $\mathrm{p} 21^{\mathrm{WAF} 1 / \mathrm{CIP} 1}$ on human liver cancer cells.

\section{MATERIALS AND METHODS}

\section{Material}

Minimum Eagle's medium (MEM), sodium bicarbonate, sodium pyruvate, penicillin-streptomycin, Trypsin-EDTA and LipofectinAMINE were purchased from GIBCO/BRL (Life Technologies, Burlington ON, Canada). Dr Alan McLachlan (Research Institute of Scripps Clinic at La Jolla, CA, USA) kindly provided PLC/ $\mathrm{PRF} / 5$ human HCC cells. HepG2 cells were purchased from ATCC (Rockville, MD, USA). Cool calf 1 and the other chemicals were purchased from Sigma Co. (St. Louis, MO, USA). The mammalian expression vector pCEP was purchased from Invitrogen (Carlsbad, CA, USA). p21 ${ }^{\text {WAF1/CIP1 }}$ and p53 antibodies were purchased from Santa Cruz Biotechnology Inc. (Santa Cruz, CA, USA). cdk2 and cdk4 antibodies, rabbit anti-mouse IgG and protein A/agarose were purchased from Transduction Laboratories (Lexington, KY, USA).

\section{Cell culture}

Two human liver cancer cell lines were employed because they represent different states of differentiation. HepG2 is a well-differentiated cell line and derived from human hepatoblastoma. PLC/ $\mathrm{PRF} / 5$ is a poorly differentiated cell line and derived from HCC of a patient with HBV. HepG2 and PLC/PRF/5 cells were grown in MEM containing 5\% Cool Calf 1 (Sigma Co. St. Louis, MO, USA) supplemented with $10 \mathrm{mmol} \mathrm{L}^{-1}$ L-glutamine, $1 \mathrm{mmol} \mathrm{L}^{-1}$ sodium pyruvate, $100 \mathrm{IU} \mathrm{ml}^{-1}$ penicillin and $100 \mu \mathrm{g} \mathrm{ml}^{-1}$ streptomycin (GIBCO-BRL, Burlington, ON, Canada) in Falcon $75 \mathrm{~cm}$ flasks. Cultures were maintained at $37^{\circ} \mathrm{C}$ in a humidified atmosphere of $95 \% \mathrm{O}_{2}$ and $5 \% \mathrm{CO}_{2}$. 


\section{RNA extraction and Northern blot analyses}

Total RNA of HepG2 and PLC/PRF/5 cells was extracted by a Lithium chloride/Urea method (Gong et al, 1995) and the polyARNA was isolated by employing oligo-dT cellular column (Aviv and Leder, 1972). Northern blot analysis was performed using $\alpha-{ }^{32} \mathrm{P}-\mathrm{dCTP}-$ labelled full-length human p $21^{\text {WAF1 }}{ }_{\mathrm{CIP} 1} \mathrm{cDNA}$ and $\beta$-actin probes as previously described (Gong et al, 1995). Briefly, $6 \mu \mathrm{g}$ of polyA- RNA was separated through $1 \%$ agarose gel, transferred onto GT-zeta nylon membrane (Bio-Rad, Burlington, ON, Canada), hybridized overnight with the probes at $42^{\circ} \mathrm{C}$ and washed as per the manufacturer's instructions.

\section{Transient transfection}

$1 \times 10^{5}$ cells were seeded in 6-well plate one day before the transfection. Mock (water), pCEP or pCEP-WAF1 was mixed with LipofectinAMINE and the mixtures were then incubated with cells for $24 \mathrm{~h}$. After $24 \mathrm{~h}$, cells were washed and incubated with culture media without antibiotics for a further $24 \mathrm{~h}$ followed by culturing in completed media for $36 \mathrm{~h}$ to allow expression of $\mathrm{p} 21^{\mathrm{WAF} / \mathrm{CIP} 1}$ gene.

\section{Cell proliferation assay}

For cell doubling time, both cell lines were plated at $1 \times 10^{5}$ cells in 6 -well plates, cell numbers were counted at days 2 and 6 after seed- ing. Cell doubling time was calculated according to the formula (doubling time $=t \times \log 2 / \log \mathrm{Nt} / \mathrm{Ni}$, where $t=$ time between the count, $\mathrm{Nt}=$ cell number at day 6 and $\mathrm{Ni}=$ cell number at day 2) as described previously (Gong et al, 1991). For ${ }^{3} \mathrm{H}$-thymidine incorporation assays, cells transfected as delineated above were labelled with $10 \mu \mathrm{Ci}$ of ${ }^{3} \mathrm{H}$-thymidine (specific activity $45 \mathrm{Ci} \mathrm{mmol}^{-1}$, Amersham, Oakville, ON, USA) for $2 \mathrm{~h}$, fixed in $10 \%$ trichloroacetic acid and lysed in $400 \mu \mathrm{l}$ of $0.2 \mathrm{M}$ sodium hydroxide. One hundred $\mu \mathrm{l}$ of the cell lysate was employed to measure $\left[{ }^{3} \mathrm{H}\right]$ thymidine incorporation with a LKB liquid scintillation counter (Wallac, Turku, Finland) and $10 \mu \mathrm{l}$ of the cell lysate was used to measure protein content by the Lowry technique.

\section{The Western blot analyses}

Cells non-transfected or transfected with mock, pCEP vector, and pCEP-WAF1 as delineated above were lysed in $100 \mu \mathrm{l}$ of $2 \times$ loading buffer $\left(125 \mathrm{mmol} \mathrm{L}^{-1}\right.$ Tris- $\mathrm{HCl}, \mathrm{pH} 6.8,4 \%$ SDS, $20 \%$ glycerol, $0.1 \%$ bromophenol blue and $2.5 \% \quad \beta$-mercaptoethanol). Twenty $\mu \mathrm{g}$ of cell lysate from each sample was separated in a $15 \%$ polyacrylamide/SDS gel, transferred onto Nitroplus-2000 membranes (Micron Separations Inc. Westborough, MA, USA) and incubated with antibodies against p53, p21 $1^{\mathrm{WAF} 1 / \mathrm{CIP} 1}$, cdk2 and cdk4 respectively. Immunoreactive bands were visualized by using the ECL (enhanced chemiluminescence) detection method (Amersham, Arlington Heights, IL, USA) (Gong et al, 1995).
A
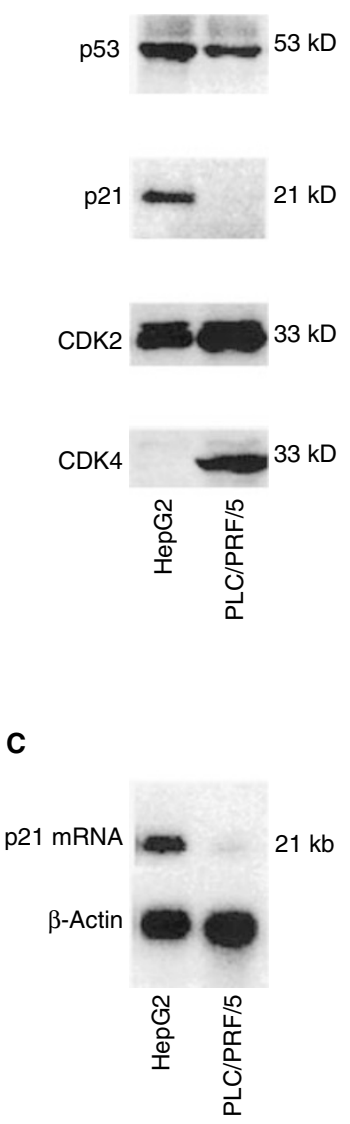

B

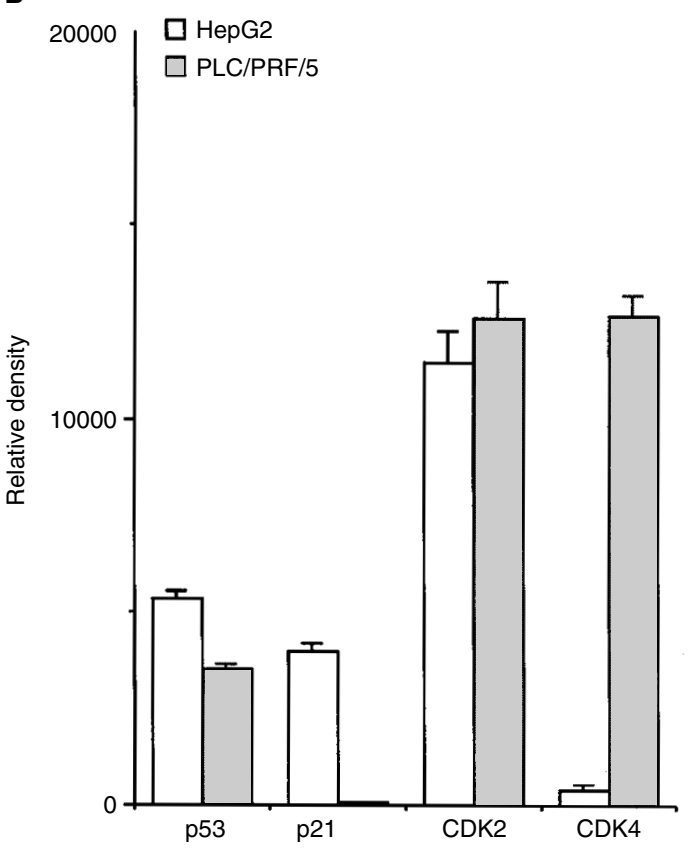

Figure I Expression of p53, p2 I WAFI/CIPI,$c d k 2$ and cdk4 in HepG2 and PLC/PRF/5 cell lines. (A) Shows Western blot analysis of p53, p2 I WAFI/CIPI, cdk2 and cdk4 in HepG2 and PLC/PRF/5 cells. Twenty $\mu \mathrm{g}$ of each cell lysate was resolved in 15\% polyacrylamide/SDS gel and incubated with antibodies against

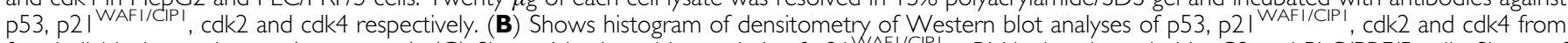
four individual experiments (mean \pm s.e.). (C) Shows Northern blot analysis of p2I WAFI/CIPI mRNA abundance in HepG2 and PLC/PRF/5 cells. Six $\mu$ g of polyA- RNA from each cell line was separated in $1 \%$ agarose and hybridized with the full length human p2I WAFI/CIP CDNA and $\beta$-actin CDNA probes respectively. 


\section{Immunokinase assay}

Immunokinase assay was performed following a protocol from Transduction Laboratories (Lexington, KY, USA). Briefly, cells with no transfection and transfection of mock, pCEP vector, and pCEPWAF1 as described above were lysed in $1 \mathrm{ml}$ cold lysis buffer (10 mmol L ${ }^{-1}$ Tris-HCl pH 7.4, 1.0\% Triton X-100, 0.5\% Nonidet $\mathrm{P}-40, \quad 150 \mathrm{mmol} \mathrm{L}^{-1} \mathrm{NaCl}, 20 \mathrm{mmol} \mathrm{L}^{-1}$ Sodium fluoride, $0.2 \mathrm{mmol} \mathrm{L}^{-1}$ sodium ortho-vanadate, $1.0 \mathrm{mmol} \mathrm{L}^{-1}$ EDTA, $0.2 \mathrm{mmol} \mathrm{L}^{-1} \mathrm{PMSF}$ ) for $30 \mathrm{~min}$ at $4^{\circ} \mathrm{C}$. One $\mathrm{mg}$ of the total cell lysate was employed to incubate with $5 \mu \mathrm{g}$ of mouse monoclonal antibodies against cdk2 and then with the same amount of rabbit anti-mouse IgG. After centrifugation, the immune complexes were further incubated with $10 \mu \mathrm{l}$ of the $50 \%$ protein A: agarose suspension. The immunocomplexes were suspended in $40 \mu \mathrm{l}$ of kinase buffer $\left(10 \mathrm{mmol} \mathrm{L}^{-1}\right.$ Tris- $\mathrm{HCl}$ pH $7.4,150 \mathrm{mmol} \mathrm{L}^{-1} \mathrm{NaCl}$, $10 \mathrm{mmol} \mathrm{L}^{-1} \mathrm{MgCl}_{2}, 0.5 \mathrm{mmol} \mathrm{L}^{-1}$ DTT) with $25 \mu \mathrm{M}$ ATP, $2.5 \mu \mathrm{Ci}\left[{ }^{32} \mathrm{P}-\gamma\right]-\mathrm{ATP}$ and $1 \mathrm{mg} \mathrm{ml}^{-1}$ histone 1 and then incubated at $37^{\circ} \mathrm{C}$ for $15 \mathrm{~min}$. The reactions were then electrophoresed on $15 \%$ SDS - PAGE and kinase activities were indicated by the band of histone 1.

\section{RESULTS}

We employed two human liver cancer cell lines to investigate the direct effect of $\mathrm{p} 21^{\mathrm{WAF} 1 / \mathrm{CIP} 1}$ on these cells. The two human liver
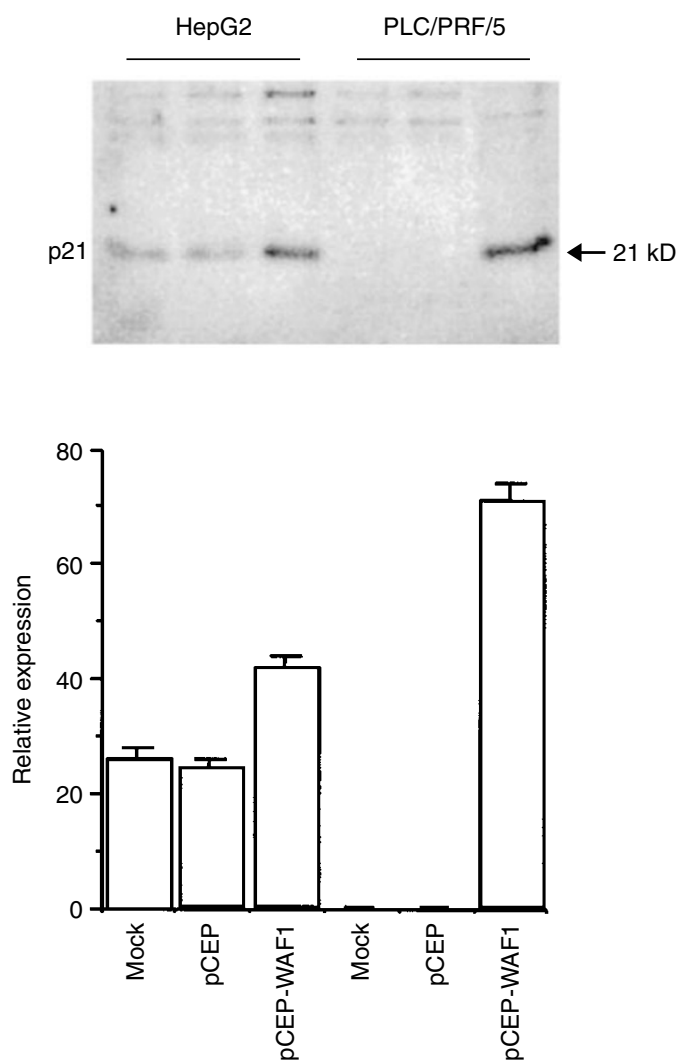

Figure 2 The upper panel shows Western blot analyses of transfected p2 I WAFI/CIPI protein in HepG2 and PLC/PRF/5 cells. Both cell lines were transfected with mock (with water), PCEP $(2 \mu \mathrm{g})$ and PCEP-WAFI $(2 \mu \mathrm{g})$. Twenty $\mu \mathrm{g}$ of each cell lysate was resolved in I5\% SDS-PAGE and transferred onto Nitroplus-2000 membrane. The membranes were then incubated with antibody against $\left.\mathrm{p} 2\right|^{\mathrm{WAF}|/ C| \mathrm{PI}}$. The lower panel shows histogram of densitometry of Western blot analyses of transfected P2 $I^{\text {WAFI/CIPI }}$ protein in both cell lines. The data represents mean \pm s.e. $(n=4)$. cancer cell lines - HepG2 and PLC/PRF/5 exhibited very different expression pattern of p53, p $21^{\mathrm{WAF} 1 / \mathrm{CIP} 1}$, cdk2 and cdk4. By Western blot analyses, p53, p $21^{\mathrm{WAF} 1 / \mathrm{CIP} 1}, \mathrm{cdk} 2$ and $\mathrm{cdk} 4 \mathrm{can}$ be detected in HepG2 cells while p53, cdk2 and cdk4 were observed in PLC/PRF/5 cells (Figure 1A). Moreover, the abundance of p53 protein in HepG2 cells was higher than that of $\mathrm{PLC} / \mathrm{PRF} / 5$ cells. Furthermore, cdk4 protein level was higher in $\mathrm{PLC} / \mathrm{PRF} / 5$ cells than in HepG2 cells (Figure 1B). Although $\mathrm{p} 21^{\mathrm{WAF} 1 / \mathrm{CIP} 1}$ protein was not observed in PLC/PRF/5 cells, its
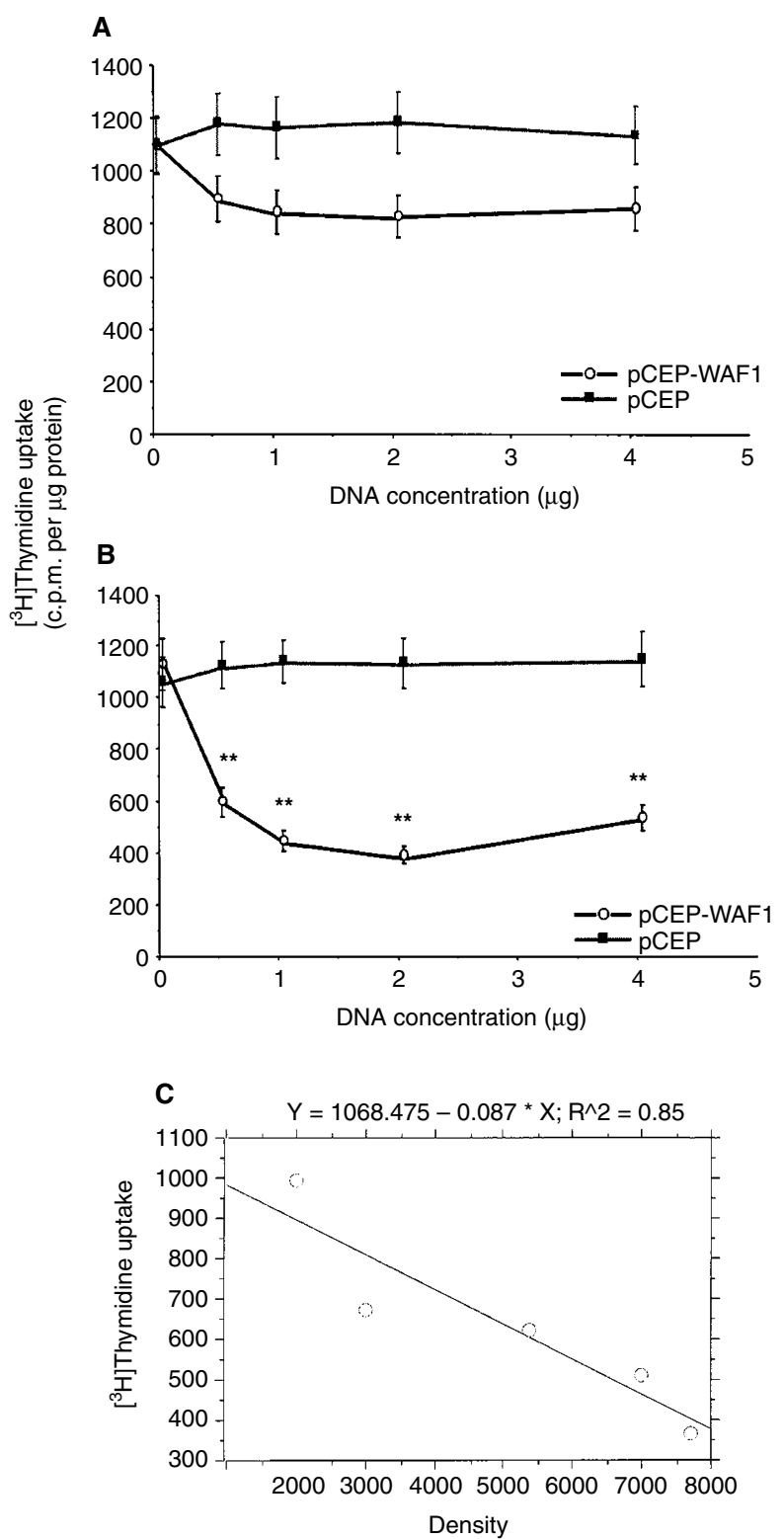

Figure 3 The effect of $\mathrm{p} 2 \mathrm{I}^{\mathrm{WAFI} / \mathrm{CIPI}}$ on $\left.{ }^{3} \mathrm{H}\right]$ thymidine incorporation in HepG2 and PLC/PRF/5 cells. (A) Shows the effect of different concentrations of PCEP and PCEP-WAFI on $\left[{ }^{3} H\right]$ thymidine incorporation in HepG2 cells. The data represents mean + s.e. $(n=8)$. (B) Shows the effect of different concentrations of pCEP and PCEP-WAFI on $\left[^{3} \mathrm{H}\right]$ thymidine incorporation in PLC/PRF/5 cells. The data represents mean + s.e. $(n=8)$. *** Indicates $P<0.01$. (C) Displays correlation between densities of $\mathrm{p} 2 \mathrm{I}^{\mathrm{WAFI} / \mathrm{CIPI}}$ and $\left[{ }^{3} \mathrm{H}\right]$ thymidine uptake in PLC/PRF/5 cells. Cells were transfected with 0.1 , $0.5,0.75,1$ and $2 \mu \mathrm{g}$ of $221^{\text {WAFI/CIPI }}$ cDNA. The densities of $\mathrm{p} 21^{\text {WAFI' }}$ Cipl protein and ${ }^{3} \mathrm{H} H$ thymidine uptake were plotted by StatView regression program. There is a statistically significant correlation between thymidine uptake and density $(P=0.0258)$. 
mRNA was expressed at low level in PLC/PRF/5 cells as compared to that in HepG2 cells (Figure 1C). Furthermore, the expression of $\mathrm{p} 21^{\mathrm{WAF} 1 / \mathrm{CIP} 1}$ was related to longer cell doubling time (HepG2 cells $44 \pm 4 \mathrm{~h}$ vs PLC/PRF/5 cells $29 \pm 3 \mathrm{~h}$, $P<0.05)$. Under the same transfection condition, the p21 level as the result of transfection in $\mathrm{PLC} / \mathrm{PRF} / 5$ cells was four times than that in the HepG2 cells. However, the total p21 levels in $\mathrm{PLC} / \mathrm{PRF} / 5$ cells after transfection was about twice of that in the HepG2 cells (Figure 2).

The effects of $\mathrm{p} 21^{\mathrm{WAF} 1 / \mathrm{CIP} 1}$ on cell proliferation of two human liver cancer cells were shown in Figure 3 . The p $21^{\text {WAF1/CIP } 1}$ inhibited cell proliferation of both HepG2 and PLC/PRF/5 cells with different extent. Although lower than pCEP vector control, the p2 $21^{\text {WAF1/CIP1 }}$ did not significantly inhibit HepG2 cell proliferation (Figure 3A). However, the p $21^{\mathrm{WAF} 1 / \mathrm{CIP} 1}$ inhibited PLC/PRF/5 cell proliferation in a dose-dependent manner. Progressive increases in the amount of transfected $\mathrm{p} 21^{\mathrm{WAF} 1 / \mathrm{CIP} 1} \mathrm{cDNA}$ resulted in a progressive inhibition of $\mathrm{PLC} / \mathrm{PRF} / 5$ cell proliferation until maximum inhibition was obtained at $2 \mu \mathrm{g}$ of the $\mathrm{p} 21^{\mathrm{WAF} 1 / \mathrm{CIP} 1} \mathrm{cDNA}$. When compared to cell proliferation associated with transfection of the pCEP vector alone, the differences were statistically significant $(P<0.01$, Figure $3 \mathrm{~B})$. Moreover, inhibition of $\left[{ }^{3} \mathrm{H}\right]$ thymidine incorporation was correlated with the expression of $\mathrm{p} 21^{\mathrm{WAF} 1 / \mathrm{CIP} 1}$ protein in PLC/PRF/5 cells (Figure 3C). To elucidate the mechanism of $\mathrm{p} 21^{\mathrm{WAF} 1 / \mathrm{CIP} 1}$ inhibition of cell proliferation, we examined the $\mathrm{p} 21^{\mathrm{WAF} 1 / \mathrm{CIP} 1}$ regulation of cdk2 and cdk4 in both PLC/PRF/5 and HepG2 cells. Our results showed that the p21 $1^{\text {WAF1/CIP1 }}$ did not alter either cdk2 or cdk4 proteins in these cells (Figure $4 \mathrm{~A}$ ). The cdk2 kinase activity was further examined by immunokinase assay. Although cdk2 kinase activity was higher in PLC/PRF/5 cells than that in HepG2 cells, the p $21^{\mathrm{WAF} 1 / \mathrm{CPP} 1}$ reduce cdk2 kinase activity by $20 \%$ in both cells (Figure $4 \mathrm{~B}$ ).

\section{DISCUSSION}

$\mathrm{p} 21^{\mathrm{WAF} 1 / \mathrm{CIP} 1}$ was identified as a potential mediator of $\mathrm{p} 53$ protein and a co-immunoprecipitated protein of cyclin D1 (Xiong et al, 1992; el-Deiry et al, 1993). Extensive studies reveal that p21 WAF1/ CIP1 involves in the progression of cell cycle. It inhibits several cyclin-cdk activities and also is a component of proliferating nuclear antigen (PCNA) and DNA polymerase $\delta$ complexe (Sherr and Roberts, 1995). The p $21^{\mathrm{WAFl} / \mathrm{CP} 1}$ protein contains two functional domains, which are mediated in the inhibition of cdk kinase and binding of PCNA. The amino end of p21 WAF1/CIP1 contains an inhibitory domain of cdk, which inhibits cyclin D and E associated cdks activities. The carboxyl end of $\mathrm{p} 21^{\mathrm{WAF} 1 / \mathrm{CIP} 1}$ mediates the PCNA-binding and activity of DNA polymerase $\delta$ (Chen et al, 1995; Luo et al, 1995; Nakanishi et al, 1995; Warbrick et al,

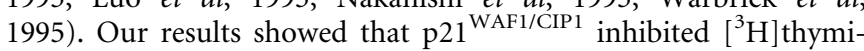
dine incorporation and reduced $\mathrm{cdk} 2$ kinase activity in human liver cancer cells but did not affect expression of cdk2 and cdk4. The findings suggest that the transfected $\mathrm{p} 21^{\mathrm{WAF} 1 / \mathrm{CIP} 1}$ likely has no apparent effect on the expression of cdks but may block the ability of PCNA to activate DNA polymerase $\delta$ and the cdk kinase activity in human liver cancer cells. The distinguished action of $\mathrm{p} 21^{\mathrm{WAF} 1 /}$ CIP1 was demonstrated in a SV40-based DNA replication system. In this in vitro DNA replication system, p2 $21^{\text {WAF1/CIP1 }}$ was able to block PCNA-activated DNA polymerase $\delta$ activity without the participation of cyclin-bound cdks (Flores-Rozas et al, 1994; Waga et al, 1994).

The role of $\mathrm{p} 21^{\mathrm{WAF} 1 / \mathrm{CIP} 1}$ in tumorgenesis of human hepatocellular carcinoma (HCC) is not clear. However, reduction of p21 WAF1/ ${ }^{\mathrm{CIP} 1}$ mRNA and protein abundance was observed in human HCC (Naka et al, 1998; Qin et al, 1998). Studies of $\mathrm{p} 21^{\mathrm{WAF} 1 / \mathrm{CIP} 1} \mathrm{mRNA}$ abundance in human HCC from Chinese and Japanese groups showed some controversies (Naka et al, 1998; Qin et al, 1998). The difference could be due to the infection of different hepatitis viruses as well as non-viral infection. One of the Japanese groups

A

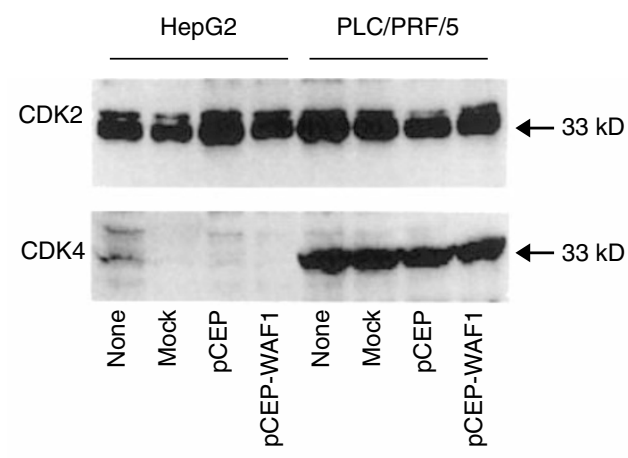

B

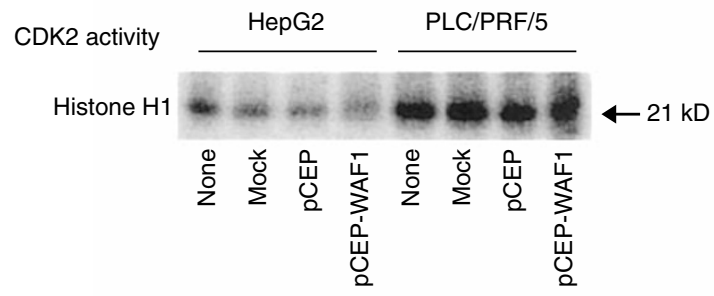

C

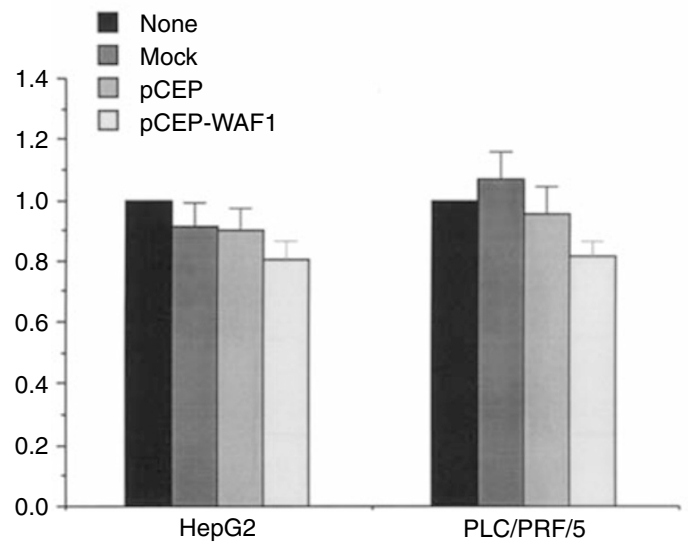

Figure 4 Both HepG2 and PLC/PRF/5 cells were treated as indicated none - no transfection, mock - transfection with water, pCEP vector and PCEP-WAFI. (A) Shows the effect of $\mathrm{p} 2 \mathrm{I}^{\mathrm{WAFI} / \mathrm{CIPI}}$ on cdk2 and cdk4 protein abundance in these cells. Twenty $\mu$ g of each cell lysate was used for Western blot analyses and the experiment was repeated on three occasions. (B) Shows the effect of cdk2 kinase activity in these cells. The cell lysates (I $\mu \mathrm{g}$ of each) were immunoprecipitated with anti-CDK2 antibody and the immunoprecipitates were incubated with a reaction solution for in vitro phosphorylation of histone $\mathrm{HI}$ as described in Materials and Methods. Samples were then electrophoresis and phosphorylated histone I was visualized by autoradiography of the slab gels. (C) Displays the histogram of cdk2 kinase activity. The data was generated from four separated experiments and represented as mean \pm s.e. The no transfection was arbitrarily set as I.

showed that HCC developed from p53-altered and HCV infected patients exhibited reduced $\mathrm{p} 21^{\mathrm{WAF} 1 \mathrm{CIP} 1}$ protein abundance while there was little change of $\mathrm{p} 21^{\mathrm{WAF} 1 / \mathrm{CIP} 1}$ protein level in those patients with $\mathrm{HBV}$ infection or no viral infection (Shi et al, 2000). Their finding was supported by that HCV core protein inhibited the promoter activity of $\mathrm{p} 21^{\mathrm{WAF} / \mathrm{CIP} 1}$ gene (Ray et al, 1998). But the reduction of $\mathrm{p} 21^{\mathrm{WAF} 1 / \mathrm{CIP} 1}$ mRNA abundance in HCC could be more complicated because of p53 gene status in 
HCC. In this study, we employed a HCC cell line - PLC/PRF/5 cells, which were derived from an African man with HBV infection and carry HBV genome (Aden et al, 1979; Koch et al, 1984). However, we observed that there was no expression of $\mathrm{p} 21^{\mathrm{WAF} 1}$ ${ }_{\mathrm{CIP} 1}$ protein and the induced expression of $\mathrm{p} 21^{\mathrm{WAF} 1 / \mathrm{CIP} 1}$ protein significantly inhibited $\left[{ }^{3} \mathrm{H}\right]$ thymidine incorporation in PLC/PRF/5 cells. Because there is a mutation of p53 gene in PLC/PRF/5 cells (Hsu et al, 1993), the absence of $\mathrm{p} 21^{\mathrm{WAF} 1 / \mathrm{CIP} 1}$ protein in PLC/ $\mathrm{PRF} / 5$ cells could be related to p53 gene rather than viral infection. It is consistent with HepG2 cells because HepG2 cells carry wild type p53 gene and no HBV genome (Hosono et al, 1991). In these cells, the $\mathrm{p} 21^{\mathrm{WAF} 1 / \mathrm{CIP} 1}$ level is higher than that in PLC/PRF/5 cells. Therefore, the $\mathrm{p} 21^{\mathrm{WAF} 1 / \mathrm{CIP} 1} \mathrm{mRNA}$ abundance in human HCC may be dependent on both the type of viral infection and p53 gene status.

One of our findings was that the expression of $\mathrm{p} 21^{\mathrm{WAF} 1 / \mathrm{CIP} 1}$ protein inhibited $\left[{ }^{3} \mathrm{H}\right]$ thymidine incorporation in human liver cancer cells no matter of whether there was viral infection or mutation of p53 genes. The difference between HepG 2 and PLC/PRF/5 cells was the degree of inhibition of $\left[{ }^{3} \mathrm{H}\right]$ thymidine incorporation. This can be due to the ratio of $221^{\mathrm{WAF} 1 / \mathrm{CIP} 1}$ and cdks because the ratio of $\mathrm{p} 21^{\mathrm{WAF} 1 / \mathrm{CI}}$ and cdks could determine whether the p53 deficient cancer cells proliferated or not (Zhang et al, 1994; Shima et

\section{REFERENCES}

Aden DP, Fogel A, Plotkin S, Damjanov I, Knowles BB (1979) Controlled synthesis of HBsAg in a differentiated human liver carcinoma-derived cell line. Nature 282: 615-616

Aviv H, Leder P (1972) Purification of biologically active globin messenger RNA by chromatography on oligothymidylic acid-cellulose. Proc Natl Acad Sci USA 69: 1408 - 1412

Chen J, Jackson PK, Kirschner MW, Dutta A (1995) Separate domains of p21 involved in the inhibition of Cdk kinase and PCNA. Nature 374: 386-388

el-Deiry WS, Harper JW, O'Connor PM, Velculescu VE, Canman CE, Jackman J, Pietenpol JA, Burrell M, Hill DE, Wang Y, Wiman KG, Mercer WE, Kastan MB, Kohn KW, Elledge SJ, Kinzler KW, Vogelstein B (1994) WAF1/CIP1 is induced in p53-mediated G1 arrest and apoptosis. Cancer Res 54: $1169-1174$

el-Deiry WS, Tokino T, Velculescu VE, Levy DB, Parsons R, Trent JM, Lin D, Mercer WE, Kinzler KW, Vogelstein B (1993) WAF1, a potential mediator of p53 tumor suppression. Cell 75: 817-825

Flores-Rozas H, Kelman Z, Dean FB, Pan ZQ, Harper JW, Elledge SJ, O'Donnell M, Hurwitz J (1994) Cdk-interacting protein 1 directly binds with proliferating cell nuclear antigen and inhibits DNA replication catalyzed by the DNA polymerase delta holoenzyme. Proc Natl Acad Sci USA 91: $8655-8659$

Gong Y, Anzai Y, Murphy LC, Ballejo G, Holinka CF, Gurpide E, Murphy LJ (1991) Transforming growth factor gene expression in human endometrial adenocarcinoma cells: regulation by progestins. Cancer Res 51: 5476-5481

Gong Y, Blok LJ, Perry JE, Lindzey JK, Tindall DJ (1995) Calcium regulation of androgen receptor expression in the human prostate cancer cell line LNCaP. Endocrinology 136: 2172-2178

Hosono S, Lee CS, Chou MJ, Yang CS, Shih CH (1991) Molecular analysis of the p53 alleles in primary hepatocellular carcinomas and cell lines. Oncogene 6: $237-243$

Hsu IC, Tokiwa T, Bennett W, Metcalf RA, Welsh JA, Sun T, Harris CC (1993) p53 gene mutation and integrated hepatitis B viral DNA sequences in human liver cancer cell lines. Carcinogenesis 14: 987-992

Hui AM, Kanai Y, Sakamoto M, Tsuda H, Hirohashi S (1997) Reduced p21(WAF1/CIP1) expression and p53 mutation in hepatocellular carcinomas. Hepatology 25: 575-579

Hunter T, Pines J (1994) Cyclins and cancer. II: Cyclin D and CDK inhibitors come of age. Cell 79: 573-582

Koch S, Freytag von Loringhoven A, Kahmann R, Hofschneider PH, Koshy R (1984) The genetic organization of integrated hepatitis B virus DNA in the human hepatoma cell line PLC/PRF/5. Nucleic Acids Res 12: 6871-6886

Luo Y, Hurwitz J, Massague J (1995) Cell-cycle inhibition by independent CDK and PCNA binding domains in p21Cip1. Nature 375: 159-161 al, 1998). In our case, that $\mathrm{PLC} / \mathrm{PRF} / 5$ cells expressed no p2 $1^{\mathrm{WAF} 1 / \mathrm{CIP} 1}$ but higher cdk4 level made it more susceptible to the inhibitory effect of $\mathrm{p} 21^{\mathrm{WAF} 1 / \mathrm{CIP} 1}$. HepG2 cells expressed $\mathrm{p} 21^{\mathrm{WAF} 1 / \mathrm{CIP} 1}$ and had lower cdk4 level, therefore, HepG2 cells were less sensitive to the effect of $\mathrm{p} 21^{\mathrm{WAF} 1 / \mathrm{CIP} 1}$

In conclusion, our present study has shown that: (a) HepG2 and $\mathrm{PLC} / \mathrm{PRF} / 5$ have distinguished expression pattern of $\mathrm{p} 53, \mathrm{p} 21^{\mathrm{WAF} 1 /}$ CIP1, and cdk4; (b) although both cells exhibited the same level of cdk2, activity of cdk2 was higher in PLC/PRF/5 cells than in HepG2 cells; (c) p21 $1^{\text {WAF1/CIP1 }}$ inhibited $\left[{ }^{3} \mathrm{H}\right]$ thymidine incorporation and cdk2 kinase activity in both HepG2 and PLC/PRF/5 cells, however, the most significant inhibition was observed in PLC/PRF/5 cells; (d) since p21 ${ }^{\mathrm{WAF} 1 / \mathrm{CIP} 1}$ inhibited DNA synthesis of human liver cancer cells, p $21^{\mathrm{WAF1} / \mathrm{CIP} 1}$ could be a target gene for the treatment of human HCC.

\section{ACKNOWLEDGEMENTS}

This work was supported by a grant from the Manitoba Medical Services Foundation. We thank Dr B Vogelstein (John Hopkin Medical School, Baltimore, MD, USA) for the pCEP-WAF1 construct.
Naka T, Toyota N, Kaneko T, Kaibara N (1998) Protein expression of p53, p21WAF1, and $\mathrm{Rb}$ as prognostic indicators in patients with surgically treated hepatocellular carcinoma. Anticancer Res 18: $555-564$

Nakanishi M, Robetorye RS, Adami GR, Pereira-Smith OM, Smith JR (1995) Identification of the active region of the DNA synthesis inhibitory gene p21Sdi1/CIP1/WAF1. EMBO J 14: 555-563

Noda A, Ning Y, Venable SF, Pereira-Smith OM, Smith JR (1994) Cloning of senescent cell-derived inhibitors of DNA synthesis using an expression screen. Exp Cell Res 211: 90-98

Qin LF, Ng IO, Fan ST, Ng M (1998) p21/WAF1, p53 and PCNA expression and p53 mutation status in hepatocellular carcinoma. Int J Cancer 79: $424-428$

Ray RB, Steele R, Meyer K, Ray R (1998) Hepatitis C virus core protein represses p21WAF1/Cip1/Sid1 promoter activity. Gene 208: $331-336$

Sherr CJ, Roberts JM (1995) Inhibitors of mammalian G1 cyclin-dependent kinases. Genes Dev 9: 1149-1163

Shi YZ, Hui AM, Takayama T, Li X, Cui X, Makuuchi M (2000) Reduced p21(WAF1/CIP1) protein expression is predominantly related to altered p53 in hepatocellular carcinomas. Br J Cancer 83: 50-55

Shima N, Stolz DB, Miyazaki M, Gohda E, Higashio K, Michalopoulos GK (1998) Possible involvement of p21/wafl in the growth inhibition of HepG2 cells induced by hepatocyte growth factor. J Cell Physiol 177: $130-136$

Skapek SX, Rhee J, Spicer DB, Lassar AB (1995) Inhibition of myogenic differentiation in proliferating myoblasts by cyclin D1-dependent kinase. Science 267: $1022-1024$

Waga S, Hannon GJ, Beach D, Stillman B (1994) The p21 inhibitor of cyclindependent kinases controls DNA replication by interaction with PCNA. Nature 369: $574-578$

Warbrick E, Lane DP, Glover DM, Cox LS (1995) A small peptide inhibitor of DNA replication defines the site of interaction between the cyclin-dependent kinase inhibitor p21WAF1 and proliferating cell nuclear antigen. Curr Biol 5: 275-282

Xiong Y, Hannon GJ, Zhang H, Casso D, Kobayashi R, Beach D (1993) p21 is a universal inhibitor of cyclin kinases. Nature 366: 701-704

Xiong Y, Zhang H, Beach D (1992) D type cyclins associate with multiple protein kinases and the DNA replication and repair factor PCNA. Cell 71: $505-514$

Zhang H, Hannon GJ, Beach D (1994) p21-containing cyclin kinases exist in both active and inactive states. Genes Dev 8: $1750-1758$ 